\title{
Solidarities at a distance: extending Fairtrade gold to East Africa
}

\section{Article}

\section{Accepted Version}

Creative Commons: Attribution-Noncommercial-No Derivative Works 4.0

Fisher, E. (2018) Solidarities at a distance: extending Fairtrade gold to East Africa. The Extractive Industries and Society, 5 (1). pp. 81-90. ISSN 2214-790X doi:

https://doi.org/10.1016/j.exis.2017.08.001 Available at https://centaur.reading.ac.uk/71791/

It is advisable to refer to the publisher's version if you intend to cite from the work. See Guidance on citing.

To link to this article DOI: http://dx.doi.org/10.1016/j.exis.2017.08.001

Publisher: Elsevier

All outputs in CentAUR are protected by Intellectual Property Rights law, including copyright law. Copyright and IPR is retained by the creators or other copyright holders. Terms and conditions for use of this material are defined in the End User Agreement.

\section{www.reading.ac.uk/centaur}

\section{CentAUR}

Central Archive at the University of Reading

Reading's research outputs online 


\title{
Solidarities at a Distance: Extending Fairtrade Gold to East Africa
}

\author{
Eleanor Fisher \\ School of Agriculture, Policy and Development \\ University of Reading \\ Earley Gate \\ Whiteknights Campus \\ Reading RG6 6AR \\ United Kingdom \\ e.fisher@reading.ac.uk
}

\section{Highlights}

- Certification processes exclude the most marginalized miners

- Artisanal and small-scale mining organisations are heterogeneous

- Influence upon national formalization agendas has been limited

- Local support organisations mediate solidarities at a distance

- A regional initiative facilitates peer learning across groups and countries

- Time is needed to assess whether equitable distribution of benefits will be realised

\begin{abstract}
This article examines how Fairtrade is transforming artisanal and small-scale gold mining. Focusing on the "Extending Fairtrade Gold to Africa" project in East Africa, it demonstrates how Fairtrade is becoming embedded within local formalization contexts and organizational dynamics. The Project is at an early stage; therefore, findings consider emerging issues. By probing what solidarities at a distance imply for gold mining, the article elaborates on how artisanal and small-scale miner organisations are developing to produce gold for Fairtrade markets. Whilst recognising that Fairtrade is not targeting the most marginalised, unlicensed miners, those groups incorporated into Fairtrade are heterogeneous and have significant development needs. With the 'unfinished business' of certification and supply of Fairtrade gold to international markets only starting to be realised, time is needed to tell whether an equitable distribution of benefits from Fairtrade will be realised amongst miners and within mining communities.
\end{abstract}

Keywords: Fairtrade; gold; artisanal and small-scale gold mining; Kenya; Uganda; Tanzania 


\section{INTRODUCTION}

In October 2016, the Syanyonja Artisanal Miner's Alliance (SAMA) in Busia District, Uganda, became the first Artisanal and Small-Scale Miner's Organisation (ASMO) in Sub-Saharan Africa to be awarded certification by FLO-CERT to trade 'Fairtrade gold'. ${ }^{1}$ On hearing of success, the miners were apparently "very excited and highly motivated to meet the demand of Fairtrade buyers".2 A Kenyan ASMO, Micodepro, was certified shortly afterwards. SAMA and Micodepro are amongst nine ASMOs in Kenya, Tanzania and Uganda that are part of a project called 'Extending Fairtrade Gold to Africa'. The UK Fairtrade Foundation (FTF) with funding from a UK-based charity, Comic Relief, leads the project in collaboration with Solidaridad Netherlands (Sol-NL) and Local Support Organisations (LSOs) in Kenya, Tanzania and Uganda. The Project's overarching aim is to improve the livelihoods and working conditions for artisanal and small-scale gold miners (ASGM) through production and sale of gold certified according to the 'Fairtrade Standard for Gold and Associated Precious Metals for Artisanal and Small-Scale Mining' (hereafter the Fairtrade Standard for Gold) set by Fairtrade International (FLO).

Certification of gold using Fairtrade standards is relatively recent, raising new challenges for the fair trade movement (Hilson, 2008). These challenges relate to the pragmatics of developing standards appropriate to ASGM and of embedding notions of ethical gold within the Fairtrade system. They also relate to more fundamental concerns regarding whether regulatory governance through voluntary standards is the most appropriate means to realise positive outcomes for impoverished miners and marginalised mining communities (Fisher and Childs, 2014; Hilson et al., 2016; Spiegel, 2015). Goodman (2004: 891) has argued that creating a sense of "solidarity at a distance" means spanning a tension between ethical relations and the wily characteristics of transnational enterprise. In the case of luxury gold jewellery sold to western consumers, an "eco-chic" is needed that is capable of bridging the beauty and bonding associated with consumption and the dirt and exploitation associated with production (Luning and Thieje, 2014: 56). As Luning (2013: 162) reminds us, the materiality of gold embodies symbolic values with potential to stimulate tensions in the moral economy of fair trade.

\footnotetext{
${ }^{1}$ The term 'fair trade' is used trading partnerships and a social movement that seek equity in international trade; while 'Fairtrade' and the 'Fairtrade system' refers to the activities of the standard-setting body, Fairtrade International (FLO) (comprising the Fairtrade Foundation and 24 member organisations), the certification body FLO-CERT, Fairtrade producer networks (e.g. Fairtrade Africa), national Fairtrade organisations and Fairtrade marketing organisations (FLO-CERT, 2011).

${ }^{2}$ Personal communication, Mrs Margaret Tuhumwire to Fisher $8^{\text {th }}$ October 2016. See FTF $(2016,2017)$.
} 
Elsewhere, I have demonstrated how particular trajectories of development shape the character of fair trade in different contexts and argued that an understanding of how fair trade becomes embedded in these contexts can help improve its objective of enhancing producer livelihoods (Fisher, 1997; Fisher, 2012; Fraser et al., 2014). I propose this is also the case for gold production, which has emerged at the periphery of national development planning in countries across the African continent. As a volume of work on fair trade testifies, such development legacies frame how benefit distribution is (re)configured in relation to competing economic interests, local politics, and complex social dynamics (e.g. Arce, 2009; Fraser et al., 2014; Lyon, 2006; Lyon and Moberg, 2010; Tallontire et al., 2005).

Fair trade has come a long way since early days in the solidarity economy, taking an increasingly instrumental approach, driven by concern with reputation, brand, and shareholder value. Writing with John Childs on fair trade gold mining in Tanzania, I suggested this was too far removed from the circumstances of Tanzania's artisanal miners who do not have a corporate reputation to defend (Fisher and Childs, 2014). Certainly, as a mode of regulatory governance, certification shapes how actors give meaning to and experience the relational aspirations of fair trade (Dolan, 2010; Berlan and Dolan, 2011; Fisher and Sheppard, 2013; Hatanaka et al., 2005; Tallontire, 2000). Indeed, as Childs (2014, 2016) argues, notions of 'fairness' in gold production and trade are contested, which raises the need to ensure that the voices of ASGM operators are both heard and acted upon. Probing how solidarities at a distance arise through changes necessitated by the creation of traceable Fairtrade gold supply chains in African localities may help bring the circumstances of artisanal miners to the fore in ways that help better identify who stands to gain from Fairtrade.

Focusing on the development of fair trade standards for gold, Hilson (2008) highlights potential need to adapt models developed for tropical agri-food commodities so they are better suited to ASGM. In later work, Hilson and McQuilken (2016) explore how fair trade gold standards have been transposed from Latin America to Africa. They argue that unique challenges arise in the African context, proposing that strategies for ASGM development through fair trade need to be locally adapted. Sidestepping my reservation that similar challenges also exist in parts of South America ${ }^{3}$, they identify important issues that flow from the informal character of ASGM in Africa.

\footnotetext{
${ }^{3}$ See for example outputs from the GOMIAM knowledge network (URL http://www.gomiam.org/about-gomiam/ Accessed $6^{\text {th }}$ June 2017).
} 
The Fairtrade Standard for Gold requires that miners operate legally, according national legislation on mineral rights (FLO, 2013). The challenges to legality are, however, significant despite a contemporary push across the African continent towards formalization (Hilson \& Maconachie, 2017). Factors such as political economies favouring corporate mining, plus diminishing land area for ASGM mean the vast majority of miners remain without mineral rights (Hilson, 2008). In effect, these legacies perpetuate an entrenched "economic logic of persistent informality" (Verbrugge, 2015: 103; e.g. Fisher, 1997; Hinton, 2005; Spiegel, 2015; Van Bockstael, 2014). Nevertheless, to be Fairtrade certified miners must be part of an ASMO that has a mineral right and is an accredited entity (FLO, 2013).

For Hilson and colleagues, this context leads fair trade to focus on the "low hanging fruit" of already well-established and licensed ASGM operations, effectively "retracing” existing supply chains (Hilson et al., 2016: 240; Hilson \& McQuilken, 2016: 201). As well as excluding more impoverished, unlicensed miners, this carries the danger of elite capture - by traditional leaders, political party members, civil servants, etc. (c.f. de Haan and Geenan, 2015; Hilson, 2008; Werthmann, 2017). Such a focus leads Hilson et al. to question claims that fair trade is pro-poor. This is a substantial concern. One also raised by Fisher and Childs (2014) who demonstrate how for Tanzania an unintended consequence of the (then) FT/FM Standard aligning with formalization policies is the exclusion of the majority of artisanal miners, missing opportunities to radically rethink potential to use the market to support the interests of the marginalized.

Amongst poorer groups in mining communities are hired labourers, casual workers and people in processing supply chains, typically the majority. Labour relations in ASGM are complex, varied, and notoriously exploitative; they are also characterised by high levels of mobility. In principle, the Fairtrade Standard for Gold (FLO, 2015) addresses labour conditions by following the International Labour Organisation's (ILO) Declaration on Fundamental Principles and Rights at Work. In practice, in contexts of persistent informality and non-existent enforcement of employment law, fully encompassing these features will be vital to how Fairtrade ensures inclusion, equity and empowerment in ASGM (c.f. Cramer et al., 2014; Verbrugge and Besmanos, 2016).

Another dimension of informality relates to the informal nature of gold market transactions. Paying a 'fair' price and cutting exploitative 'middleman' relationships is at the heart of fair trade, with the Fairtrade Standard for Gold providing a 'Fairtrade Premium' for projects in mining communities (FLO, 2015a). However, as Childs $(2014,2016)$ emphasises, both the issue of what price is fair and 
the important roles 'middlemen/women' play as sponsors, bring contestations over notions of 'fairness' to the fore. Moreover, pragmatically, it raises questions regarding the unintended consequences of replacing middlemen through fair trade supply chains (Banchirigah, 2008; Hilson \& McQuilken, 2016).

Against this background, this article explores how the 'Extending Fairtrade Gold to Africa' project has sought to transform ASGM to meet the Fairtrade Standard for Gold in East Africa. Because the ASMOs are only just becoming Fairtrade certified, it focuses on the development of certified supply chains and does not consider how gold is being traded or impact of gold sales on miner's livelihoods or community development. Three questions are addressed: firstly, how does Fairtrade connect to 'on the ground' realities regarding mineral licensing and formalization? Secondly, how are miners becoming organised to trade Fairtrade gold? And, thirdly, are there aspects of the Fairtrade business model that need to be adapted for ASGM? To address these questions, the article combines learning from an external project evaluation conducted for the Fairtrade Foundation in 2015 by Kessler (AidEnvironment, Netherlands), Fisher (University of Reading, UK) and Ndaluka (Mwailimu Nyerere Academy, Tanzania) (Kessler et al., 2015), with secondary sources and past research with Tanzanian mining groups now part of Fairtrade (Fisher, 2007, 2008; Fisher et al., 2009; Mwaipopo et al., 2004).

The discussion turns first to describe the development of fair trade standards for gold, then it elaborates on the Project, before concluding with a reflection on relevant issues.

\section{CREATING A FAIRTRADE STANDARD FOR GOLD}

Impetus for the Fairtrade Standard for Gold emerged from campaigns in the 1990s and 2000s for social justice in gold production and for 'conflict free' jewellery (FTF, 2015). Campaigns included the World Gold Commission/Twin Trading's 'Apartheid-Free' gold certificate, Oxfam America/Earthworks 'No Dirty Gold', and Cafod's 'Unearth Justice' (Atkinson et al., 2009; TWIN, 1990). All shared a belief in the importance of ethical provenance for gold, although how to judge provenance and whom should approve claims, were and remain divisive issues (Oakley, 2012). A growing range of standards now exist for minerals and gemstones linked to different certification initiatives (Fisher and Childs, 2014: 133-134; Hilson et al., 2016: 283; Buxton et al., 2013: 10-13).

For the Fairtrade system, gold certification required reflection on whether it was appropriate to apply a Fairtrade standard to gold and how it could be done. As Valerio, founder of the ethical company 'Cred Jewellery' describes prosaically: 
"Here I am a jeweller, standing on the other side of a counter from a couple who want to get married; I have to know what I am selling them. Its not just a gold ring, the gold has come from somewhere ... you don't want to be dumping 20 tonnes of toxic waste down the toilet because you don't know or, more importantly, the jeweller either doesn't want to tell you or cant tell you" (BTC, n.d.). And: "gold was not bananas, tea or coffee. It was not an agricultural product, and Fairtrade Labelling did not have a reputation for working in the luxury goods market. So the challenge was: could Fairtrade certification work when applied to a high value luxury commodity such as gold" (Valerio, 2013: 108)?

Hilson and colleagues have elaborated on the background to fair trade gold (Hilson, 2008; Hilson \& McQuilken, 2016; Hilson et al., 2016). Very briefly, echoing their discussion: in the early 2000s, the Oro Verde project started to certify 'ecological gold' (Sarmiento et al., 2013). This led to the creation of a multi-stakeholder knowledge network, the Association for Responsible Mining (renamed the Alliance for Responsible Mining, ARM), which developed the Fair Trade Artisanal Gold Standard Zero (hereafter Standard Zero) (Hilson, 2008; Valerio, 2013).

In 2006, FLO and ARM began developing a shared vision of better conditions for ASGM (FTA, 2013a). In 2007-8, a scoping study was conducted on ASGM and fair trade in Africa, as described in Section 3. This included consultations with African miners and their representatives over the draft Standard Zero. There was a positive response, with miners' inspired by the concrete project in Colombia (Oro Verde) and by potential for cross-continental peer-learning (Levin et al., 2008). Miners critically questioned how the standard would take into account formalisation processes and ASGM labour divisions in East Africa, particularly when the licence-holder is not the miner. In addition, they argued that by restricting work to legal miners, Standard Zero was not oriented towards helping more vulnerable miners without a title (ibid.). They also called for locally appropriate terminology to avoid misunderstanding. In 2009, ARM entered a three-year partnership with FLO. Standard Zero became superseded by the 'Fairtrade and Fairmined Standard' (FT/FM Standard), with a dual label on certified products from Latin America when they started to appear in the UK in 2011 (FTF, 2015a).

Worldwide, expenditure on gold jewellery is amongst the largest categories of consumer goods (Fairtrade Foundation, 2015). The ARM-FLO partnership was driven by a long-term vision of capturing 5 percent of the market over 15 years (FLO, 2010). This led organisations to court high-end North American and European jewellers to make and sell certified products. FTF publicity gives 
expression to what Hilson and McQuilken (2016b: 184) described as the "feel good" story created for ASGM:

"Say I DO to Fairtrade Gold and commit to making a difference" ... "Small scale mining is one of the most dangerous industries in the world, and miners often work in very remote and harsh conditions with little or no health and safety measures in place. Fairtrade Gold offers a lifeline to these miners, their families and communities. Fairtrade gives strict standards on working conditions, women's rights, child labour and environmental management; in return miners gain access to markets and receive the Fairtrade Premium - the extra sum they receive to develop their businesses and invest into their communities" ... "This is just the beginning of this story and we want you to join in and become part of it (FTF, n.d.).”

The ARM-FLO partnership led to the inception of the 'Extending Fairtrade Gold to Africa' project described in this article. However, organisational alignment and integration of a joint standard did not last beyond 2013. In parlance of the time, ARM separated "in pursuit of greater autonomy" (FTF, 2013b). According to Hilson and McQuilken (2016), this was driven by acrimonious differences over traceability in the supply chain (also Valerio, 2013: 162). Differences hinged on whether mixing certified and non-certified gold was permissible through 'mass balance'. ${ }^{4}$ Supporters argued it contributed to an effective business model by creating volume to drive benefits to miners (ARM, 2010); detractors argued that traceability and provenance were paramount for consumers. ${ }^{5}$ Currently, the Fairtrade Standard for Gold does not permit mass balance for mined gold (FLO, 2013). ${ }^{6}$

Today, ARM certifies ASGM supply chains with the 'Fairmined Standard for Gold from Artisanal and Small-Scale Mining, including Associated Precious Metals' (hereafter 'the Fairmined Standard for Gold') (ARM, 2014), while FLO uses the Fairtrade Standard for Gold. In effect, these standards introduce into ASGM a mechanism for supply chain transparency and traceability through a 'tripartite standards regime' (c.f. Loconto and Busch, 2010: 507), which - depending on the organisation combine standard setting, auditing and accreditation by either ARM and SCS Global Services (Fairmined) or FLO and FLO-CERT (Fairtrade). Having remained a FLO/FTF project, the Extending

\footnotetext{
${ }^{4}$ Mass balance (single site or group) applies to Fairtrade cocoa, cane sugar, juice and tea (FLO, 2011).

${ }^{5}$ See URL: https//gregvalerio.com/tag/mass-balance-gold/ Accessed 6 ${ }^{\text {th }}$ June 2017.

${ }^{6}$ The Fairmined Standard for Gold has three forms of certification, two of which permit mass balance gold in the supply chain: 'Fairmined Certificates' which focus on volume of production of certified gold and its flow into legal gold supply chains, rather than physical traceability and incorporation into a specific supply chain; and 'Fairmined Incorporated' in which downstream of a Fairmined refiner, operators or licensees are free to define how they want to incorporate Fairmined gold into the supply chain; the third, 'Fairmined labelled', permits no mass balance (ARM, 2014).
} 
Fairtrade Gold to Africa project uses the Fairtrade Standard for Gold to develop supply chains from East Africa (FLO, 2013). ${ }^{7}$

Worldwide there are eight mines producing Fairmined certified gold and three producing Fairtrade certified gold. ${ }^{8}$ Gold production is in relatively small volumes, with demand outstripping supply but volumes are expanding, partly due to growth of Fairtrade supply chains, but also through greater volumes certified under the tripartite Fairmined system (Footnote 4). Trade from Africa will continue, with projects working to attain certification in at least seven sub-Saharan African countries (Kenya, Uganda, Tanzania, Ghana, Mali, Senegal and Burkina Faso). ${ }^{9}$ There are also other, often competing, standards - paralleling a wider tendency in fair trade (Bacon, 2010) - including the Responsible Jewellery Council's (RJC) Chain-of-Custody certification and the Artisanal Gold Council's Responsible Artisanal Gold ${ }^{T M}$.

\section{EMBEDDING FAIRTRADE GOLD IN EAST AFRICA}

The roots of the 'Extending Fairtrade Gold to Africa' project lie in 2006 when FLO and ARM started working together, as described in Section 2. Subsequently, in 2007, ARM led a project - "Scoping Opportunities for Developing Fair Trade Processes for ASM in Africa" - intended to pilot test (the then) Standard Zero on its first incursion into Africa. This was funded through $\$ 48,000$ from the World Bank's Development Grant Facility of the Communities and Small-Scale Mining Secretariat (CASM).

\subsection{Scoping the pilot}

ARM initially proposed piloting the project in Mozambique, Tanzania and Ghana; Sierra Leone was also considered (Levin et al., 2008). Being viewed as a partner in the process, the World Bank was

\footnotetext{
${ }^{7}$ There are two separate models for Fairtrade gold: (i) FLO's core business model, the Fairtrade Standard for Gold that is the focus of this article, which requires all operators to be registered and audited, with final products certified and punched with Fairtrade mark approval; and (ii) the Fairtrade Goldsmith's Registration Scheme for micro-jewellers to use certified gold in their designs.

${ }^{8}$ Fairmined -certified mines are in Bolivia, Colombia, Peru and Mongolia; Fairtrade-certified mines are in Peru, Uganda and Kenya.

${ }^{9}$ In addition to Extending Fairtrade Gold to Africa (2012 - 2018), projects include: the 'Responsible Artisanal Mercury Supply Chain and Reduction of Mercury Emissions in West Africa' project (Burkina Faso, Senegal, Mali) (2013-2016), the 'Face of Ghana's Gold project (2012-2015) and 'Partnering for Better Livelihoods in the Gold Supply Chain' (Ghana) (date), the Going for Gold project (Ghana, Tanzania) (2016 - 2021), and 'Global Opportunities for the Long-Term Development of the ASGM Sector' (Burkina Faso) (n.d.).
} 
influential, with Standard Zero held to align with its framework for responsible mining promoted in Uganda and Tanzania (Levin et al., 2008; Miranda et al., 2005). Thus, at an early stage, Uganda was substituted for Ghana due to a perceived potential for collaboration with the World Bank/multi-donor (2004-2011) US\$28.00m Sustainable Management of Minerals Research Project (SMMRP) (World Bank, 2003); also due to a perceived struggle by ARM to advance in Ghana (Levin et al., 2008).

ARM's scoping study included: (i) three country reports on the feasibility, desirability and needs related to production and marketing of certified sustainable gold (including consultation on Standard Zero); (ii) recommendations for institutional arrangements to move forward with local partners; and, (iii) strengthening of links and exchange between miners in Africa and Latin America, and between miners and other players in the gold and jewellery supply chain (Levin et al., 2008: 5). ARM intended that miners from Africa and Latin America would visit one another; instead, some attended the Ethical Jewellery Summit in Washington (October 2007) and three from Tanzania attended SMMRP Training in Uganda (February 2008).

Country studies took place between 2007-8 (Levin, 2007, 2008; Walshe, 2007). Logistics were organised by ARM, with its local partners being key to decisions over which mining locations and miner groups to visit. ${ }^{10}$ Overarching conclusions were, firstly, that in all countries - but notably Uganda - a key impediment was the paucity of non-governmental organisations (NGOs) to act as partners. Secondly, that there was no perfect country candidate, given governance difficulties and limited miner organisation across the region. Nevertheless, pilots were considered feasible in Tanzania and Uganda; ultimately, and for disparate reasons, only one identified miner's organisation later became an ASMO. In Mozambique, reluctance had been encountered on the part of government regarding partnership, plus miner organisation was extremely low, making a pilot difficult. With Mozambique discounted, a 2010 scoping study identified two appropriate miners' organisations in south-western Kenya, and highlighted a supportive policy environment (with viable logistics from Nairobi) (Mwasha, 2010).

\subsection{The Comic Relief-funded Project}

Subsequently, in 2012, Comic Relief awarded £800k to support the project in Kenya, Uganda and Tanzania (2012-1015). ${ }^{11}$ Overarching aims were to improve conditions in mining communities through

\footnotetext{
${ }^{10}$ ARM's local partners were Derecção Nacional de Minas Pequena Escala (DEMPE) (Mozambique); Tanzania Women Miners' Association (TAWOMA) and FBME, Ltd. (Tanzania); and the Department of Geological Survey and Mines, Ministry of Energy and Minerals (Uganda).

${ }^{11}$ In 2016, the project received a 4-year extension (£868.000).
} 
lobbying for the formalisation of mining rights, and supporting miners to achieve FT/FM certification as a vehicle for social, economic and environmental development. Six partners were brought together:

(i) FTF, providing overarching leadership in conjunction with its local network organisation, Fairtrade Africa (FTA), as the focal point for the African FT/FM network over the course of the project; facilitating knowledge exchange amongst miners and between Fairtrade farmers and miners; organising annual regional meetings; and supporting training needs identification.

(ii) Sol-NL, working with FTF to support European Fairtrade labelling initiatives to development markets for certified gold and to support brands interested in sourcing their gold from Africa; also, to oversee project monitoring and evaluation.

(iii) ARM, providing a bridge between the FT/FM pilots in Latin America and those in Africa; with emphasis was on delivery of training through regional meetings, leading public policy and advocacy work, and linking the project to international stakeholders.

(iv) Solidaridad East and Central Africa Expertise Centre (SECEAC), as the Local Support Organisation (LSO) for Kenya, including training, monitoring, and learning activities.

(v) MTL Consulting (MTL), as the LSO responsible for training and certification requirements for miners groups in Tanzania.

(vi) Environmental Women in Action for Development (EWAD), as the LSO responsible for training and certification requirements for miners' groups in Uganda.

ARM remained a partner until 2013, when other partners took over its functions (although the connection to Latin America weakened). Rather than the dual FT/FM standard and label, the Project progressed with the new Fairtrade Standard for Gold (FLO, 2015). Sol-NL continues as a partner, providing links to goldsmiths and consumers in the Netherlands; tensions do arise, however, because it offers unbiased advice on responsible sourcing options and is reluctant to exclusively promote the Fairtrade label (Kessler et al., 2015).

Between 2012 and 2015, project objectives and related outcomes were to: (i) enable 1,100 small-scale miners to mine gold in a fair and responsible manner according to the Standard; (ii) create an African knowledge network to promote responsible ASM practices, including capacity building for LSOs; (iii) influence stakeholders in their policy and decision-making towards ASM; (iv) get at least 5 jewellers to commit to sourcing Fairtrade certified gold from Africa; and, (v) increase consumer awareness in the UK and Netherlands' on ethical issues related to gold production (Kessler et al., 2015). It was planned that FTF and Sol-NL would raise interest among supply chain actors to source African 
Fairtrade gold; both organisations would also roll out a campaign in the UK and the Netherlands to inform consumers on ethical issues related to gold and support market uptake, as companies identify a new market to tap into. Experience in Latin America was that pre-certification took a minimum of 2-3 years, therefore it was envisaged that after 3 years ASMOs would undergo trial certification audits to assess compliance.

As Kessler et al. (2015) elaborate the project theory of change (TOC) ${ }^{12}$ assumed that LSOs would be trained to deliver training to miners on the Fairtrade Standard for Gold. Also, that FTA would coordinate stakeholder knowledge-sharing, promoting responsible practices across the region. FTA was envisaged as convening a Public Policy Committee to influence stakeholder views and inspire supportive policies for ASGM. Co-ordinated policy change was considered vital, given learning from the experience in Latin America that the formalisation process for ASGM communities requires integration of policies, strong co-ordination between institutions, and in some areas (e.g. tax regimes) co-ordination of policies between countries. Alongside LSO's and miners, ARM was held to be able to facilitate this public policy engagement, given existing work with UNEP in Tanzania and Uganda on formalization and mercury reduction (UNEP, 2012), and its (then) recently commissioned 'Legalization Guide for ASM' (Barreto, 2011). The TOC incorporated two 'upscaling' mechanisms to achieve greater impact: copying of responsible mining and buying practices by non-targeted mining communities and market players; and 'crowding in' whereby new actors join the initiative to further own interests (Kessler et al., 2015). A Fairtrade Gold Centre of Excellence programme has also been proposed (Stocklin-Weinberg, 2015).

\subsection{Situating Fairtrade in national formalization processes}

Project planning highlighted the need for alignment with country-level formalization to stimulate a positive public policy environment and to ensure governments take responsibility for ASGM (c.f. CFC, 2008). As elsewhere, ASGM in East Africa has historically been associated with illegality, environmental degradation, social problems, and conflict; institutional capacity for regulation and improvement has been weak. Nevertheless, sectoral development is spurring formalization (Table 2).

\footnotetext{
${ }^{12}$ A TOC makes explicit the assumptions regarding what change an initiative wishes to see and how it intends to contribute (FLO, 2015c).
} 
Having been in the vanguard of World Bank-influenced mineral sector liberalisation since the early 1990s, Tanzania has the most conducive policy, legislative and civil society environment of the three countries, with political will to formalise the sector realised through concrete actions. Even so organizational practices diverge from regulatory mechanisms, and numbers of licensed artisanal miners are small (Fisher and Childs; Jonsson \& Fold, 2014). The National Artisanal and Small-scale Mining (ASM) Formalisation Strategy (2012) seeks to build capacity in the sector through miner organisation, technological development, grants, loans, and training (Mhinda, 2014).

Compared to the substantial Tanzanian ASGM sector, both mineral sector development and the scale of ASGM in Kenya and Uganda are limited. Kenyan government has historically been 'hands-off', with no provisions for ASGM. However, the Mining Act (2016) facilitates mineral sector development and introduces ASGM formalization (NCLR, 2016). Provinces such as Nyanza (where the ASMOs are) pushed for recognition of artisanal mining in the Act. Fiscal decentralization has transferred revenue and tax raising powers to county government, and the Act establishes county-level licencing linked to multi-stakeholder Artisan Mining Committees. A 'crowding-in' of initiatives is taking place at this level.

In Uganda, mining legislation is under review. A sectoral assessment conducted by the Department of Geological Survey and Mines in 2003 (DGSM, 2003: 48) concluded: "Artisanal mining operations are unlicensed and therefore illegal. DGSM has no management or control over artisanal workers and no mandate to assist, monitor or control them". The Mining Act (2003) and Mining Regulations (2004) made 'Location Licences' possible but they are most appropriate for small-scale operations rather than artisanal mining. In reality a range of labour, fiscal, and environmental regulations apply to ASGM in an institutional set up characterised by ambiguity and informality (Hinton, 2005; CLS/EI, n.d.). Estimates suggest less than 5\% of artisanal miners hold licenses, due to areas covered by exploration licences, cost, gender barriers, etc. (UNEP, 2012: 28). Overall, 'entry points' for national dialogue on ASGM are severely constrained and institutional capacity is low.

Table 2: ASM Formalisation in East Africa

TANZANIA

Number of miners

Policy \& legislation
685,000 AS miners (2012, World Bank estimate); 3,932 licensed (2010; Fisher and Childs, 2014: 141).

Mineral Policy (2009); Mining Act (2010) 


\begin{tabular}{|c|c|}
\hline Licensing & $\begin{array}{l}\text { Seven-year Primary Mining License (PML) for capital investment }<\text { US } \$ 100,000 \text { and claim }<10 \\
\text { hectares. Licensing decentralised to Zonal Mines Offices. A PML can be granted inside another } \\
\text { (large-scale) mineral right. }\end{array}$ \\
\hline Land rights & $\begin{array}{l}\text { In past a PML owner had the right to land above ground, in principle this has changed but } \\
\text { mining continues to take precedence over land rights. }\end{array}$ \\
\hline Formalization & $\begin{array}{l}\text { Policy and legislation provides scope for ASM, with formalisation embraced in the 1990s. The } \\
\text { Mining Act (2010) prescribes co-existence between ASM and large-scale mining, citizen } \\
\text { ownership, and integration with other economic sectors. }\end{array}$ \\
\hline \multicolumn{2}{|l|}{ KENYA } \\
\hline Number of miners & 100,000 direct participants; 10,000 ASGM in south-west Nyanza Province (Mwasha, 2010) \\
\hline Policy \& legislation & $\begin{array}{l}\text { Pre-2016 mining law was silent on ASM. The Mining Act (2016); Mining and Minerals Policy } \\
\text { (2016) grant mineral rights to ASM. }\end{array}$ \\
\hline Licensing & $\begin{array}{l}\text { Post-2016: an Artisanal Mining Permit may be acquired by adult Kenyan nationals who are } \\
\text { members of a co-operative, association or group; fractions of large-scale blocks may be granted } \\
\text { to small-scale mining; land may also be reserved for ASM. }\end{array}$ \\
\hline Land rights & $\begin{array}{l}\text { Land rights take precedence over mineral rights and express consent has to be given by the } \\
\text { registered land owner; typically land owners who charge high fees (ore) and make contractual } \\
\text { changes. Pits remain under the jurisdiction of land owners and are kept open for future tenants } \\
\text { rather than refilling for safety or environmental reasons. }\end{array}$ \\
\hline Formalization & $\begin{array}{l}\text { The Mining Act (2016) provides for formalization. According to the Constitution, responsibility } \\
\text { for minerals remains with - recently created - national institutions; however, the Mining Act } \\
\text { (2016) establishes multi-stakeholder, county-level Artisan Mining Committees. }\end{array}$ \\
\hline \multicolumn{2}{|l|}{ UGANDA } \\
\hline Number of miners & $\begin{array}{l}\text { Growing numbers; } 130,000 \text { people directly employed and } 800,000 \text { indirectly employed; } 11,000 \\
\text { to } 13,000 \text { mine gold (2005) (Hinton, 2005). }\end{array}$ \\
\hline Policy \& legislation & $\begin{array}{l}\text { The Mining Act (2003), Mining Regulations (2004) and related policy are under review. At } \\
\text { present, the Commissioner of Mines holds discretionary powers, with lack of clarity over } \\
\text { institutional roles; proposed revisions establish a more conducive institutional environment. }\end{array}$ \\
\hline Licensing & $\begin{array}{l}\text { According to the Mining Act (2003), ASM is permitted through a location licence for operations } \\
\text { without substantial expenditure or sophisticated technology. }\end{array}$ \\
\hline Land rights & With a location licence, agreements must be made with landowners but this is under review. \\
\hline Formalization & $\begin{array}{l}\text { The mining sector is dominated by ASM (about 90\%) but negative attitudes prevail, } \\
\text { underpinned by limited scope for formalisation until draft legislation enacted. }\end{array}$ \\
\hline
\end{tabular}

In summary, the Project sits within national contexts where formalization is occurring, despite significant governance challenges. Opportunities for the Fairtrade initiative to link to wider processes were and are strongest in Tanzania, but are emerging in Kenya and - to a lesser extent - Uganda. It is within these contexts that partners sought to develop Fairtrade Gold supply chains, which meant enrolling LSOs, establishing ASMOs, and building capacity.

\subsection{The LSOs}

The ARM country scoping studies envisaged that local organisations would implement the initiative (Levin, et al., 2008). Nevertheless, this was regarded as challenging however, given limited civil society organisation in ASGM. In the event, three organisations were identified: EWAD, established 
by the wife of the Director of the Department of Geological Survey and Mines, is a small but stable NGO, with experience of ASM, including for the SMMRP. MTL is a private consultancy introduced in the absence of strong NGO candidates. Its director, a mining engineer, had implemented earlier projects with two ASMOs in Geita. SECEAC, a regional expertise centre of Solidaridad, became the LSO for Kenya. Staff of all LSOs had excellent ASM-relevant skills, experience and connections; nevertheless, capacity building was needed to progress fair trade (Kessler et al., 2015). ARM conducted initial LSO training and later FTA. ${ }^{13}$

Alongside their own capacity building activities, LSOs had to recruit miner groups. Project localities are concentrated on greenstone belt north and south of Lake Victoria. In Uganda, EWAD initially considered two districts, Busia and Karimoja, but the logistics and insecurity of working in Karimoja led to a focus on Busia. Artisanal miners have worked the Busia gold field since the 1930s, however there is a critical need for productive improvement and market development (DGSM, 2003; Hinton, 2005). One group in Busia had been a recipient of SMMRP training, but EWAD had to initiate others. In Kenya, ASGM is concentrated in the south-west with similar development needs to Busia; the focal region and miner groups were identified in 2010 (Mwasha, 2010). In Tanzania, Geita was identified by the scoping study; given MTLs existing links, it became the focal area.

\subsection{The ASMOs}

ASMOs are the primary vehicle for miners to apply for Fairtrade certification, to produce and trade Fairtrade gold, and to use the Fairtrade premium for community projects (see Table 1). Driven at an early stage by $\mathrm{ARM}^{14}$, the Fairtrade Standard promotes membership-based 'Artisanal and Small-Scale Miners Organisations' (ASMOs) to improve working conditions and build organisational and lobbying capacity. This raises challenges in East Africa where ASGM has limited history of collective organisation. The Mining Act of Kenya (2016) includes provision for cooperatives, associations and groups, but Tanzanian and Ugandan legislation are silent.

\section{Table 3: Fairtrade ASMOs in East Africa (2015)}

\begin{tabular}{l}
\hline KENYA - MIGORI AND LOLGORIAN DISTRICTS \\
\hline Mining Community Development Programme (Micodepro) - established: 1999 (alluvial and hard rock mining) \\
\hline Prospecting Right license: 2005 ; Milling License: 2013 ; Environmental Licence: 2014 ; Not yet acquired Export \\
Licence \\
Registered community based organisation (CBO), Ministry of Social Services. \\
Members: 20 men/11 women; executive committee: 3 (1 woman); when pits are not waterlogged up to 150 workers \\
\hline Challenges: expiry of land lease, owner doubling rates; relocation; heavy rainfall stops production; access to capital. \\
\hline 13 Training included finance, reporting templates, etc.; later also on the Fairtrade Standard, advocacy, first aid, mining \\
curriculum development, etc. \\
${ }^{14}$ Personal communication, Greg Valerio, 1st March 2017.
\end{tabular}


Lolgorian Local Miners Cooperative (Lolgorian) (not visited) - established:1970s (hard rock mining)

Registered in 2006 as a cooperative; but hasn't acquired all its licenses.

52 members ( 32 female)

Challenges: weak leadership; migrants, for mining and due to politics; rainfall stops production; access to capital.

\section{UGANDA - BUSIA DISTRICT}

Busia United Small-scale Miner's Organisation (BUSMO) - established: 2010 (alluvial \& hard rock, 8 open cast pits)

Registered 2011. Association sub-county registered: 2011; Company Certificate of Incorporation: 2011; Location

Licence: 2012 (13.2 hectares); plan to apply for 21 year mining lease

3 'directors' (men/land-owners), 50 members (37 men, 13 women), 25-30 labourers

Challenges: In 2000s, larger-scale Busitema (Greenstone) Mining Company acquired license for area, residents complained and government advised formation of associations; limited technical knowledge; need equipment \& operating capital; dangerous open caste pits, methods improving; internal conflicts; fluctuating numbers; profits to members not reinvested.

Tiira Small-scale Miners Association (TIISMA) - established: 2011 (alluvial \& hard rock; 2 open cast pit / panning Land rights: ASMO Location license (memorandum of understanding (MoU) with BUSMO); unregistered association. Executive committee (4 men, 3 women); started with 51 but men left, now 22 members (16 women, 6 men); 1 pit 20 labourers: 1 pit 14-15 (numbers fluctuate) - strong female leadership.

Challenges: work together but profits shared between individuals, little committed to the ASMO; limited technical knowledge; need equipment \& operating capital. Dangerous open caste pits, methods improving; Greenstone Mining need to relinquish land for TIISMA to hold licence.

Buteba Small-Scale Miners Association (BASMA) - established: 2013 (hard rock; 1 open cast pit)

7 members (6 men, 1 woman)

Mineral rights: MoU with BUSMO; Land rights: written agreement; 1 member is land-owner

Challenges: ASMO unregistered; just forming; rich deposit but lack of capital and equipment; difficulties retaining members due to non-operational pit. Started with 52 members but most left.

Syanyonja Miners' Alliance (SAMA) (alluvial and hard rock, open caste / shaft)

Established: 2012 (with 94 members, approximately 250 seasonal workers); now fewer

Registered: Association (sub-county); Land rights: landowner in charge of mine; Mineral rights: MoU with BUSMO

Challenges: after start up internal conflict; mine collapse; flooding; limited technical knowledge; need equipment \& operating capital; debt.

\section{TANZANIA - GEITA REGION}

Nsangano Gold Mine (hard rock ore; shaft; manual /explosives)

Privately owned by family; Prospecting Licence Claim: 1986 (started as gold buyer); Nsangano Traders: 1989; PML: 1995 ( 7 held by father, then his offspring); Presidential Environment Award: 2005; Mining License: 2010 (2 PML claims amalgamated, now focus of Fairtrade project)

5 family directors ( 2 women); 29 permanent workers; 6 casual workers (gender unknown)

Key challenges: Mine became dormant in 2008 - lack of capital, unreliable market, old equipment created operational downtime. Has access to credit.

Mawemeru Gold Mine (Golden Hainga) (hard rock)

Privately owned, small-scale mining enterprise (Companies Ordinance); PML: 1999 (held by one man)

Forest logging rights

Members: number/gender not known.

Key challenges: Not operational - main shareholder withdrew due to internal conflict.

Umoja Lwamgasa Savings and Credit Cooperative Society (SACCOs) (ULS) (hard rock; shaft; impact hand drilling/explosives)

Community-based organisation (CBO) (Cooperatives Act); Certificate of Registration as SACCO: 2007; PML: 2009

(held by ASMO); Explosives permit

Members: 8 women (2 leaders), 71 men

Key challenges: Lack of capital; weak leadership; mine rush 2009; no mining operation; SACCO sub-leasing 4 pits. Two projects: Msisi gold mine / 2 Village Community Banks (VICOBA). Money from SACCO financing mine unreturned.

Referring to Table 3, in Tanzania, the project includes three ASMOs: Mawemeru Gold Mine, Lwamgasa SACCO, and Nsangano Gold Mine. In 2015, only the latter was operational (Kessler et al., 2015). Mawemeru had internal conflicts and its major shareholder, Golden Hainga, withdrew to try to 
develop a small-scale operation elsewhere. Lwamgasa SACCO had leadership weaknesses and lacked capital. Comparison demonstrates differences between the ASMOs. In the 2000s, the Tanzanian government promoted miner group formation for access to mining land and loans (linked to the World Bank SMMRP and National ASM Development Strategy). Consequently, Geita District Cooperative Office enabled Lwamgasa to establish a SACCO. ${ }^{15}$ However, they experienced a mine rush in 2009 (25 pits); government advised the SACCO to take $10 \%$ of production and leave $90 \%$ to informal pitowners (Kessler et al., 2015). In 2015, the SACCO was sub-contracting 4 operating pits. Following Fairtrade entrepreneurship training, it established two Village Community Banks (VICOBA).

In contrast, Nsangano Gold Mine is a small-scale private company mining an old colonial shaft. Chachage (1993) describes how in the 1980s Dar Tardine Tanzania Ltd used sub-contractors to buy gold from "illegal" miners. Nsangano ${ }^{16}$ and Golden Hainga were sub-contractors who later led the Regional Miners' Association, MWAREMA, being well-placed to access projects. Nsangano's operation has benefited significantly from donors, including DFID and UNIDO; UNEP recognised him as environmentalist of the year and in 2005, he won the Presidential Environment Award (Fisher, 2008; Kessler et al., 2015). FBME provided a loan in the late 2000s and ARM funded training in Uganda by SMMRP (Levin, 2008). Between 2010 and 2014 an agreement was held with Hanbora Mining Ltd. of Korea, however it did not realise profit (Kessler et al., 2015). Nsangano is deceased but the five current directors are his children.

In Kenya there are similar differences: Micodepro is a registered CBO established in 1999. In 2015, it had 31 permanent members led by a bishop with leadership skills. He was subsequently employed by the Fairtrade project to support other ASMOs and act as chair of the newly established ASM network for Kenya (Kessler et al., 2015). Micodepro has attracted donor, government and private sector support. In contrast, Lolgorian is beset by leadership weaknesses and operational difficulties. The Masai are indigenous (non-mining) inhabitants but Luo and others move through the area due to mining opportunities, but also local politics, and this undermines stable leadership. For both Micodepro and Lolgorian conflict arises with landowners; for example, in 2014 the landlord closed access to Lolgorian's productive pits and by mid-2015 a new pit was still not operational.

\footnotetext{
${ }^{15}$ SACCO's are widespread across East Africa and not specific to ASGM.

${ }^{16}$ The "successful mining entrepreneur" documented under a pseudonym in Fisher (2008).
} 
In Busia, ASGM is long-established, tending to occur within settled communities. Colonial workings provide access to small but high grade vein quartz mineralization (DGSM, 2003). However, mining practices are dangerous and destructive, with limited technological development. BUSMO is led by three director/landowners who started with the operation with two others in 1998. Following a 6-year dispute with Busitema (Greenstone) Mining Company, which sought to take over areas worked by artisanal miners, government prompted BUSMO to become a registered association to provide security against exploration activities. In 2012 BUSMO obtained a Location Licence, renewed in 2014 and in 2016 it intended to apply for a twenty-one year Mining Lease (Kessler et al., 2015). The 2015 evaluation identified internal conflicts between the directors (one landowner moved away and others cannot mine his pits), undermining ASMO operations (ibid.).

In contrast, BASMA, TIISMA and SAMA are start-ups of the Fairtrade project although they build on colonial workings, which individuals have mined for years. When the ASMOs started they attracted many members hoping for inputs but who later left. Only a few members of BASMA remained in 2015 and the mine was not operational due to capital constraints, despite excellent geological potential. SAMA had been the most promising ASMO in terms of organisational development, in 2015 it was not operational but once restored it achieved Fairtrade certification. TIISMA an 'up and coming' ASMO is interesting: it too attracted many members but most men left disillusioned when no foreign inputs were forthcoming. In the words of women members: "they were impatient for benefits" ... "they showed their true colours" ... "they wanted to come back but we didn't take them" (Fisher, 2015); Thus today TIISMA is female dominated with leadership that includes an articulate female secondary school teacher.

While the 'ASMO' as an organizational form is new, the nine groups reflect wider histories of formalization, group formation, and tenure relations (land, minerals) as embedded within local dynamics and organizational forms. This includes how past interventions and opportunities have been grasped by individuals, how power relations are played out, and the dynamics of local g development and miner mobilities.

\subsection{ASMO membership}

The 2015 evaluation included primary data on ASMO membership, local employment, and community wellbeing (Fisher, 2015; Kessler et al., 2015). Space precludes elaboration, however briefly: all the 
functional ASMOs had consolidated management and committee structures and improved employment conditions. There was nevertheless a sense of cooperative organisation being 'overlaid' on existing relations and power structures relating to individual claims, miner group histories and local land rights; some ASMOs were more inclusive than others. As identified above, some also had leadership weaknesses. The degree to which women have a voice ranges from tokenism (e.g. BUSMO) to greater empowerment (e.g. TIISMA). Children are not employed by the ASMOs, although child mining labour is a common issue. Table 3 identifies member numbers; these are however shareholdermembers not labourers/workers, for which numbers are more fluid, relating to e.g. productivity and season. Labourers will remain a significant part of the workforce within the ASMOs and being amongst the poorest people in mining communities, as sales of Fairtrade certified gold start to be realised, adequate attention needs to be paid to their employment rights and livelihood needs.

\subsection{Developing the system of production}

In all three countries, LSOs have provided substantial training contributing to changing practices related to mercury use, safety, pit construction, first aid, gender aspects and child labour (Kessler et al., 2015). Impacts are greatest in Uganda, where initial awareness was lowest. For more 'technical' aspects including pit construction, mine site rationalisation, and establishing systems of production (SYSPRO) and internal control systems (ICS), there has been significant improvement. However, ongoing LSO support is required (Kessler et al., 2015). On organisational and management aspects there have also been significant improvements, including in relation to employment rights and democratic structures, although the starting point was low, with even bookkeeping being a challenge.

One success has been peer learning. The Evaluation found this was much appreciated by miners and there was evidence that knowledge, skills and technology were being exchanged (Kessler et al., 2015). Micodepro and Lolgorian visited Sireet Outgrowers (tea) and Kabug'etung Farmers' Cooperative Society (coffee) and valued exposure to Fairtrade operations. Following a visit to Nsangano in Tanzania, SAMA constructed timbered mine shafts; having seen Tanzanian 'krushas', BUSMO miners invested in ball mills, moving away from pestle/mortar. Lolgorian established a savings scheme to purchase processing technology after visiting Lwamgasa. A recently installed 'gold kacha concentrator' at SAMA is exciting interest from neighbouring miners, with the prospect of reducing child labour in processing. ${ }^{17}$ There was also evidence of some external miners copying practices, especially with immediate effects on health and safety, productivity, and processing labour.

${ }^{17}$ See: http://cred.org.uk/gold/ and, www.youtube.com/watch?v=GszK2JfdIBs Accessed $6^{\text {th }}$ June 2016. 
With LSO support, Micodepro in Kenya, Nsangano in Tanzania, and BUSMO and SAMA in Uganda were mock audited by FLO-CERT in 2015. Nevertheless, a severe bottleneck for reliably consolidating systems of production and trade is that ASMOs have to cease operations when mine shafts cannot be used (due to flooding or land title problems). This is a common phenomenon in all three countries, having been the case for Micodepro, MaweMeru, SAMA, Umoja Lwangasa and BUSIITEMA. Leadership problems undermine organisational consolidation and are reinforced by capital constraints feeding into low productivity. Our evaluation stated that 'proof of concept' (that ASMOs could be established and Fairtrade certified within a few years) was not evident (Kessler et al., 2015). Perhaps we were wrong because the first ASMO to gain certification was SAMA started in 2012. Nevertheless, it takes time to develop internal cohesion and leadership, and to empower women; moreover, access to capital and equipment to build robust and responsible operations remains a core challenge. LSO support remains vital, as do inputs provided by separate donations e.g. CRED Foundation for a gold katcha and the Belgian Trade Centre for training and demonstrations in Uganda.

\section{$3.9 \quad$ Trading gold}

The ASMOs were not Fairtrade certified in 2015 so findings on trade are limited. In each location, there are local buyers who supply e.g. mercury, provisions, capital, money for diesel (pumps); gold is also sold in towns like Kampala, Migori and Mwanza. How the ASMOs move from local sales to trading internationally, and whether pre-finance from international clients (indispensable within the business model) will take over 'middle-men' roles are untested. The pragmatics of exporting Fairtrade gold through government and private systems also has to become established.

'Activist' jewellers have clearly been important for developing capacity to trade on international markets and in marketing Fairtrade solidarities at a distance within Europe, facilitated by e.g. the 'Goldsmiths Registration Scheme' (FTA, 2014). Greg Valerio and Pippa Small have made 'commercial engagement' visits to Uganda; Bibi van der Velden, Cox \& Power, and Ingle \& Rhode collaborate in European Fairtrade campaigns (FTA, 2015; Kessler et al., 2015; Luning and de Thieje, 2014; Valerio, 2013). A "gold miner" (Dan Odida, General Secretary from MICODEPRO), has "toured" jewellers and Fairtrade groups in the UK. In the high-end luxury jewellery market, this is a relational business where putting a face on ethical provenance matters; these relations also support LSOs and ASMOs as they progress.

\section{DISCUSSION AND CONCLUSIONS}


This article has explored the creation of new solidarities at a distance through the introduction of Fairtrade certification for ASGM in East Africa. Developing a standard for Fairtrade gold has involved an iterative process between different actors, across continents and in regional and country contexts, which has incorporated learning from the East African experience. As ever, development practice is a messy, contingent and ambiguous process and the conclusion of the 2015 evaluation was that the Extending Fairtrade Gold to Africa project is 'unfinished business'. Given that no miners had been certified to trade Fairtrade gold, this was hardly surprising. Even so, the fact that SAMA, the first ASMO in Africa to become Fairtrade certified in 2016, was not operational in August 2015 due to mine collapse highlights the fragility of current supply chains. It also underlines the need for caution when drawing conclusions at such an early stage, hence findings focus on emerging issues.

In consultations for ARM over Standard Zero in 2007, miners in East Africa expressed concerns over how problematic it was to focus exclusively on those with a license, effectively excluding many others and being especially tricky when the license-holder is not a miner themselves. These are fundamental issues. By targeting licensed operators, certification according to the Fairtrade Standard for Gold excludes the majority of people working within the sector, as highlighted by existing literature. In effect, as a market intervention and form of regulatory governance, Fairtrade has not sought to 'step outside the formalization box' to target the most impoverished miners. Project partners of Extending Fairtrade Gold to Africa recognise how problematic is the issue of formalization, and project plans aspire to influence public policy in ways supportive of ASGM. In reality though, by 2015, wider policy influence had been limited. This was perhaps understandable given that energy focused on ASMO formation, LSO and ASMO capacity building, and Fairtrade certification. Moreover, while the formalisation agenda is advancing in Tanzania to include ever greater numbers of miners, there are significant barriers to engaging with policy makers and stimulating civil society advocacy in Kenya and Uganda. Nevertheless, there has also been a tendency for the Project to work in isolation from other initiatives.

Within these wider policy contexts, one sees how Fairtrade is becoming embedded in ASGM in ways that reflect the messy reality of 'formalization in practice'. In Tanzania, all three ASMOs have held PMLs since before the Project started. For one ASMO, however, the 'economic logic of persistent informality' rears its head in the form of sub-leasing to non-licensed pit-holders. Kenya provides a contrast, given that there was limited legal basis for ASGM until 2016. One ASMO holds licenses and is a registered CBO while the other is not. In Uganda, in the 2000s, mineral rights were adapted for small-scale mining; nevertheless, the size of claim-holdings is relatively large. One ASMO has a 
Location Licence that others 'sit within' through Memoranda of Understandings. The three active ASMOs are also registered associations at sub-county level. Furthermore, in both Kenya and Uganda, access to minerals has to be negotiated with landowners through informal agreements that create conflict and insecurity. These are not tenure arrangements that Fairtrade has managed to transform; how new policy and legislation will affect the situation remains to be seen.

Processes of inclusion and exclusion also arise regarding which miner groups are incorporated into Fairtrade and how they are organised. One can ask whether Fairtrade is simply targeting the 'lowhanging fruit' of the most organised small-scale operators, as Hilson and colleagues argue. In East Africa, this is by no means straightforward. Nsangano Gold Mine in Tanzania clearly fits the lowhanging fruit bill, being a 'rationalised' small-scale operation that has benefited from successive interventions, including those implemented by the LSO. Nevertheless, the Project also includes ASMOs organised along cooperative lines with low levels of development. Indeed, the first ASMO to become certified was amongst three in Uganda started with LSO support; moreover, Busia is a district where mining development is extremely low. Thus, there are significant differences in ASMO histories, inclusiveness and levels of organisation; it is not simply a case of elite capture of benefits that could be better deployed elsewhere, or of Fairtrade retracing existing supply chains. In this regard, it is worth underlining how influential has been the role of LSOs as mediators in solidarities at a distance, helping to identify and enrol mining groups, shaping ASMO engagement, liaising with partners, engaging with stakeholders, and facilitating regional peer-learning.

Feeding into ASMO development is a further issue, namely access to capital to develop the mining operations. This was a challenge confronting the Project in its first three years, prior to any ASMO becoming certified, because Comic Relief does not provide capital investment. Even with committed members (which most are), mine collapse and flooding, in part the result of poor equipment and limited operating capital, endanger reliable operations. This led the 2015 evaluation to call into question the 'proof of concept' of the Fairtrade business model, which relies on international markets and traders for such investment. Gavin Hilson (2008) has made the valuable point that gold supply chains are different from other Fairtrade agri-food commodities; the need for investment to develop robust, stable operations with technology to facilitate responsible practices maybe where approaches to Fairtrade mining need to differ from other Fairtrade supply chains. An argument can be made, of course, that technological advancement through investment may lead to greater inequality, with growing productivity benefits in the hands of the few. But it is also the case that without significant returns on production or when mines close, an itinerant, marginalised workforce, environmentally destructive 
practices, and reliance on exploitative 'middle-man' relations become self-perpetuating. There aren't easy solutions to either ASGM development or social equity. Indeed, at present, how the ASMOs develop over time, what their impact on local mining practices will be, how wider influencing roles play how, and how burdens and benefits will be distributed, is 'unfinished business' yet to be judged.

If we accept that gold certification through voluntary standards such as Fairtrade are here to stay, while recognising the limitations of regulatory governance 'within the box' of national formalization agendas, one can ask pragmatically how best to move forward to generate the maximum benefits for marginalised ASGM. In this respect, there is scope for new partnerships to develop - for example with companies able to provide finance; for institutional synergies - for example with social protection programmes for the most vulnerable in mining communities; and for learning opportunities to be exploited - for example, as planned, centres of excellence that facilitate peer knowledge transfer.

\section{Acknowledgements}

I would like to thank Jan Joost Kessler of AidEnvironment for many thought-provoking communications; Steven van Bockstael and two anonymous reviewers for helpful peer feedback. Also, to express my gratitude to Margaret Tuhumwire of Environmental Women's Action in Development and mining groups in Busia District, Uganda. 


\section{References}

Alliance for Responsible Mining [ARM], 2014. Fairmined standard for gold from artisanal and small-scale mining, including associated precious metals. Version 2.0.

Alliance for Responsible Mining [ARM], 2013. Expandiendo el Oro Fairtrade \& Fairmined en África, ARM Boletín 1.

Arce, A., 2009. Living in times of solidarity: Fair trade and the fractured life worlds of guatemalan coffee farmers. J. Int. Dev. 21, pp. 1031-1041. doi:10.1002/jid.1634

Atkinson, J. and Scurrah, M., 2009. Globalizing Social Justice: The Role of Non-Government Organizations in Bringing about Social Change Palgrave MacMillan.

Bacon, C.M. 2010. Who Decides What is Fair in Fair Trade? The Agri-Environmental Governance of Standards, Access and Price, Journal of Peasant Studies, 37(1): 111-147. doi:

\section{$10.1080 / 03066150903498796$}

Banchirigah, S.M., 2008. Challenges with eradicating illegal mining in Ghana: A perspective from the grassroots, Resources Policy 33(1), pp. 29-38.

Barreto, M.L. 2011. Legalization Guide for ASM. ARM series on responsible ASM No 5. https://www.yumpu.com/en/document/view/34487295/legalization-guide-for-artisanal-andsmall-scale-mining-asm Accessed 6th June 2017.

Berlan, A. and Dolan, C., 2011., Of red herrings and immutabilities: Rethinking fairtrade's ethic of relationality among cocoa producers, Goodman, C. and Sage, C. (eds.) Food transgressions: Making sense of contemporary food politics. London: Ashgate. pp. 39-60.

Blackmore, E., Holzman, C., Buxton, A., 2013. Scaling up certification in artisanal and small-scale mining: Innovations for inclusivity. IIED: London.

BTC Trade for Development (date not documented). Fair Trade Gold from Peru. http://www.befair.be/en/content/documentary-fair-trade-gold-peru Accessed 06 June 2016.

Childs, J. 2014. From 'criminals of the earth' to 'stewards of the environment': The social and environmental justice of Fair Trade gold, Geoforum 57, pp.129-137. doi: 10.1016/j.geoforum.2014.08.2016

Childs, J., 2014. A new means of governing artisanal and small-scale mining? Fairtrade gold and development in Tanzania. Resources Policy 40, pp. 128-136. doi:10.1016/j.resourpol.2014.01.007

Colombia Law School / Earth Institute [CLS/EI] (date not documented) Comments on Uganda's Mining Act and Regulations. http://ccsi.columbia.edu/files/2014/05/CCSI-review-of-Ugandamining-legislation-Jan-28.pdf Accessed 6th June 2017. 
Common Fund for Commodities [CFC], 2008. Regional workshop: Small-scale mining in Africa: A case for a sustainable livelihood.

Crammer, C., Johnston, D., Oya, C., Sender, J., 2014. Fairtrade cooperatives in Ethiopia and Uganda: Uncensored, Review of African Political Economy 41(1), pp. S115-S127. doi: 10.1080/03056244.2014.976192.

Department of Geological Survey and Mines [DGSM], 2003. Sectoral Environmental and Social Assessment for the MSDTA Project. DGSM: Entebbe, Uganda.

Dolan, C., 2010. Fractured Ties: The business of development in Kenyan fair trade tea, in: Lyon, S. and Moberg, M. (eds.) Fair trade and social justice: global ethnographies. New York University Press: New York and London. pp. 147-175.

Fairtrade Africa [FTA], 2013a. Fairtrade gold kick off in Kisumu. http://www.fairtradeafrica.net/news/fairtrade-gold-kick-off-in-kisumu-2/

Fairtrade Africa [FTA], 2013b. Fairtrade miners and farmers share experiences. http://www.fairtradeafrica.net/news/fairtrade-miners-and-farmers-share-experiences/ Accessed 6th June 2017.

Fairtrade Foundation [FTF], 'Fairtrade brings hope to Uganda's artisanal gold mines. URL: http://www.fairtrade.org.uk/Media-Centre/Blog/2017/January/Fairtrade-brings-hope-toUgandas-artisanal-gold-mines Accessed 6th June 2017.

Fairtrade Foundation [FTF], 2016. 'Fairtrade certificates first artisanal and small-scale mining cooperative in Africa' URL: https://www.fairtrade.net/new/latest-news/singleview/article/fairtrade-certifies-first-artisanal-small-scale-mining-cooperative-in-Africa.html Accessed 6th June 2017.

Fairtrade Foundation [FTF] (date not documented) 'I Do' http://ido.fairtrade.org.uk/why-fairtradegold/ Accessed 6 ${ }^{\text {th }}$ June 2017.

Fairtrade Foundation [FTF], 2015a. 'I DO’ http://www.fairtrade.org.uk/en/mediacentre/news/january-2015/fairtrade-bridal-campaign-i-do-launches-on-iconic-steps-of-st-paulscathedral

Fairtrade Foundation [FTF], 2014. Fairtrade Small Jeweller Scheme Opens for Business. http://www.fairtrade.org.uk/en/media-centre/news/april-2014/fairtrade-small-jeweller-schemeopens-for-business Accessed 6th June 2017.

Fairtrade International [FLO], 2015. Fairtrade theory of change. FLO: Bonn.

Fairtrade International [FLO], 2013. Fairtrade standard for gold and associated precious metals for Artisanal and Small-Scale Mining. v.1.2 www.fairtrade.net Accessed 16 ${ }^{\text {th }}$ July 2016.

Fairtrade International [FLO], 2011. Explanatory document for the Fairtrade trade standard. 
https://www.fairtrade.net/fileadmin/user_upload/content/2011-12-

29_Explan_Doc_GTS_EN.pdf Accessed 6th June 2017.

Fairtrade International [FLO], 2010. FLO and ARM launch Fairtrade and Fairmined Gold Standards. http://www.fairtrade.net/new/latest-news/single-view/article/flo-and-arm-launch-fairtrade-andfairmined-gold-standards.html Accessed 6th June 2017.

Fisher, E., Attah, R., Barca, V., O'Brien, C., Brook, S., Holland, J., Kardan, A. and Pozarny, P., 2017. The livelihood impacts of cash transfers in sub-Saharan Africa: beneficiary perspectives from six countries. World Development. doi: 10.1016/j.worlddev.2017.05.020 (In Press)

Fisher, E., 2015. External evaluation of extending Fairtrade gold to Africa project, Appendix 7c: Uganda case study report. Fairtrade Foundation: London.

Fisher, E., 2012. The "Fair Trade Nation": Market-oriented development in devolved European regions, Human Organisation 71(3). pp. 255-267.

Fisher, E., 2009. Introduction: the policy trajectory of fair trade. Journal of International Development, 21 (7), pp. 985-1003. doi: 10.1002/jid.1633

Fisher, E., 2008. Artisanal gold mining at the margins of mineral resource governance: a case from Tanzania. Development Southern Africa, 25 (2), pp. 199-213. doi: $10.1080 / 03768350802090592$

Fisher, E., 2007. Occupying the margins: Labour integration and social exclusion in artisanal mining in Tanzania. Development and Change, 38 (4). pp. 735-760. doi: 10.1111/j.14677660.2007.00431.x

Fisher, E., 1997. Beekeepers in the global 'fair trade' market: a case from Tabora Region, Tanzania. International Journal of the Sociology of Agriculture and Food, 6, pp. 109-159.

Fisher, E. and Childs, J. 2014. An Ethical Turn in African Mining: Voluntary Regulation through Fair Trade, in: Bryceson, D.F., Fisher, E., Bosse Jønsson, J., Mwaipopo, R. (Eds.), Mining and Social Transformation in Africa: Mineralizing and Democratizing Trends in Artisanal Production. Routledge, London, pp. 130-147.

Fisher, E., Mwaipopo, R., Mutagwaba, W., Nyange, D., Yaron, G., 2009. “The ladder that sends us to wealth": Artisanal mining and poverty reduction in Tanzania. Resour. Policy 34, 32-38. doi:10.1016/j.resourpol.2008.05.003

Fisher, E. and Sheppard, H., 2013. Pushing the boundaries of the social: private agri-food standards and the governance of Fair Trade in European public procurement. International Journal of the Sociology of Agriculture and Food, 20 (1). pp. 31-49. ISSN 0798-1759

Fraser, J., Fisher, E. and Arce, A. (2014) Reframing 'crisis' in fair trade coffee production: trajectories of agrarian change in Nicaragua. Journal of Agrarian Change, 14 (1). pp. 52-73. 
ISSN 1471-0366 doi: 10.1111/joac.12014

FLO-CERT, 2011. Fair Trade Glossary. doi:10.1111/1475-4932.12136

Goodman, M.K., 2004. Reading fair trade: Political ecological imaginary and the moral economy of fair trade foods. Polit. Geogr. 23, 891-915. doi:10.1016/j.polgeo.2004.05.013

National Council for Law Reporting [NCLR], 2016. Mining Act No 12. The Republic of Kenya. http://kenyalaw.org/lex/rest//db/kenyalex/Kenya/Legislation/English/Acts\%20and\%20Regulatio ns/M/Mining\%20Act\%20No.\%2012\%20of\%202016/docs/MiningAct12of2016.pdf Accessed $6^{\text {th }}$ June 2017.

Haan, de J. and Geenan, S., 2016. Mining cooperatives in Eastern DRC : Saviour or exploiter? The interplay between historical power relations and formal institutions, Extractive Industries and Society 3 (3), pp. 823-831. doi: 10.1016.jexis.2016.05.003.

Hilson, G., 2008. "Fair trade gold": Antecedents, prospects and challenges. Geoforum 39, 386-400. doi:10.1016/j.geoforum.2007.09.003

Hilson G.M., Maconachie R., 2017. Formalizing Artisanal and Small-Scale Mining: Insights, Contestations and Clarifications. Area, doi: 10.1111/area.12328

Hilson, G.M, Hilson, A., McQuilken, J., 2016. Ethical minerals: Fairer trade for whom? Resour. Policy 49, 232-247. doi:10.1016/j.resourpol.2016.05.002

Hilson, G.M., McQuilken, J. 2016. Moving overseas? Critical reflections on the implementation of Latin American ethical gold schemes in Sub-Saharan Africa, in: Mining in Latin America: Critical Approaches to the New Extraction. Routledge, London, pp. 184-210.

Hinton, J., 2009. National Strategy for the Advancement of Artisanal and Small Scale Mining in Uganda, Report to Ministry of Energy and Mineral Development, Uganda.

Kessler, J.J., Ndaluka, T.J., Fisher, E., 2015. External evaluation of Extending Fairtrade Gold to Africa project 1-69. doi:10.13140/RG.2.1.4173.6088

Levin, E., 2008a. Scoping Study for Fairtrade-Certified Artisanal Gold: Tanzania. ARM.

Levin, E., 2008b. Scoping Study for Fairtrade-Certified Artisanal Gold: Uganda. ARM.

Levin, E., Walshe, N., Echavarría, C., 2008. Scoping Opportunities for Developing Fair Trade Processes for ASM in Africa. Project Assessment Report for Artisanal Gold in Mozambique, Tanzania and Uganda.

Loconto, A. and Busch, L., 2010. Standards, techno-economic networks, and playing fields:

Performing the global market economy, Review of International Political Economy, 17(3), pp.507-539.

Luning, S., 2013. Gold from 'Rock to Ring', Etnofoor, 25(5), pp.159-174.

Luning, S. De Theije, M., 2014. Global Gold Connections: Ethical Consumption and the Beauty of 
Bonding Artisans, in Barendregt, B. Jaffe, R. (eds.) Green Consumption: The Global Rise of Eco-Chic. Bart Barendregt, Rivke Jaffe.

Lyon, S., 2006. Evaluating fair trade consumption: politics, defetishization and producer participation. Int. J. Consum. Stud. 30, 452-464. doi:10.1111/j.1470-6431.2006.00530.x

Lyon, S.M., Moberg, M., 2010. Fair trade and social justice: global ethnographies, Fair trade and social justice: global ethnographies. doi:10.1177/0094306111412516

Mhinda, A.M., 2014. Scoping study of public policy engagement for Artisanal and Small Scale Mining in East Africa. Fairtrade Africa: Nairobi.

Mwaipopo, R., Mutagwaba, W., Nyange, D., Fisher, E., 2004. Increasing the Contribution of Artisanal and Small-Scale Mining To Poverty Reduction in Tanzania. Rep. Prep. Deparment Int. Dev. UK 1-153.

Mwasha, T. 2010. Scoping Study for Fairtrade-Certified Artisanal Gold: Kenya. London, Fairtrade Foundation.

Nelson, V. and Pound, B., 2009. The last ten years: A comprehensive review of the literature on the impact of Fairtrade. Fairtrade Foundation: London.

Oakley, P., 2012. Reflections on ethical gold, The Goldsmiths' Company Technical Bulletin.

OECD. 2013. Due Diligence Guidance for Responsible Supply Chains of Minerals from Conflict Affected and High-Risk Areas, $2^{\text {nd }}$ Edition. OECD https://www.oecd.org/corporate/mne/GuidanceEdition2.pdf Accessed 15th July 2017.

Parry, M., 2017. Fairtrade brings hope to Uganda's artisanal gold mines. URL:

http://www.fairtrade.org.uk/Media-Centre/Blog/2017/January/ Fairtrade-brings-hope-toUganda's-artisanal-gold-mines/ accessed $6^{\text {th }}$ June 2017.

Spiegel, S.J., 2015a., Contested diamond certification: Reconfiguring global and national interests in Zimbabwe's Marange fields. Geoforum 59, pp. 258-267. doi:10.1016/j.geoforum.2014.05.008 Spiegel, S.J., 2015b., Shifting formalization policies and recentralizing power: The case of Zimbabwe's artisanal gold mining sector, Society and Natural Resources 28(5), pp. 243-558. doi: 10.1080/08941920.2015.1014606.

Stocklin-Weinberg, R., 2015. Feasibility study for fairtrade gold centre of excellence programme. Fairtrade International.

Tallontire, A., Dolan, C., Smith, S., Barrientos, S., 2005. Reaching the marginalised? Gender value chains and ethical trade in African horticulture. Dev. Pract. 15, pp. 559-571. doi:10.1080/09614520500075771

Tallontire, A., 2000. Partnerships in fair trade: Reflections from a case study of Café ' direct, Development in Practice, 10(2), pp. 166-177. doi: 10.1080/09614520050010205 
TWIN. 1990. 'Alternative gold jewellery', The Network 3(1). London: Twin Trading.

UNEP (2012) Analysis of Formalization Approaches in the Artisanal and Small-Scale Gold Mining Sector Based on Experiences in Ecuador, Mongolia, Tanzania and Uganda: Uganda Case Study.

Van Bockstael, S., 2014. The persistence of informality: Perspectives on the future of artisanal mining in Liberia, Futures 62, pp. 10-20.

Verbrugge, B. and Besmanos, B., 2016. Formalizing artisanal and small-scale mining: Whither the workforce? Resources Policy 47, pp. 134-141.

Verbrugge, B., 2015. The Economic Logic of Persistent Informality: Artisanal and Small-Scale Mining in the Southern Philippines, Development \& Change 46(5), pp. 1023-1046. doi: 10.1111/dech.12189

Valerio, G., 2013. Making Trouble: Fighting for Fair Trade Jewellery. Lion Hudson plc: Oxford. Walshe, N., 2007. Scoping Study for Fairtrade-Certified Artisanal Gold: Mozambique. ARM. Werthmann, K., 2017. The Drawbacks of Privatization: Artisanal Gold Mining in Burkina Faso 1986-2016. Resources Policy 52, 418-426.

World Bank, 2015. Sustainable Management of Mineral Resources Project : Phase 2 [Tanzania] http://documents.worldbank.org/curated/en/277301468113344662/pdf/E47700SMMRP0P100Box38 5436B00PUBLIC0.pdf Accessed 6th June 2017.

World Bank, 2003. Sustainable Management of Mineral Resources Project: Phase 1 [Uganda] http://projects.worldbank.org/P079925/sustainable-management-mineral-resources-project? lang=en \&tab= overview Accessed $6^{\text {th }}$ June 2017. 